\title{
PENGARUH CITRA MEREK DAN LIFESTYLE TERHADAP KEPUTUSAN MEMBELI SEPATU PETER KEIZA DI MATAHARI DEPARTMENT STORE CITO SURABAYA
}

\author{
Istiqomah Novitasari ${ }^{1}$, I Ketut Surabagiarta ${ }^{2}$, Evita Purnaningrum ${ }^{3}$ \\ Mahasiswa Program Studi Manajemen Fakultas Ekonomi \\ Universitas PGRI Adi Buana Surabaya \\ istiqomahnovitasari435@gmail.com
}

\begin{abstract}
ABSTRAK
Penelitian ini bertujuan untuk mengetahui pengaruh citra merek dan lifestyle terhadap keputusan membeli sepatu peter keiza di matahari department store Cito Surabaya karena dari beberapa tahun kemarin mengalami penurunan yang sangat drastis untuk itu saya berinisiatif mencari salah satu penyebab turunnya minat pembeli di matahari cito surabaya dengan variabel citra merek dan lifestyle untuk sampel yang digunakan sebanyak 154 responden. Variabel yang digunakan penelitian ini terdiri dari variabel bebas (citra merek dan lifestyle) dan variabel terikat (keputusan membeli). Untuk penentuan jumlah sampel digunakan dengan teknik accidental sampling dan menggunakan metode analisis regresi linier berganda. Hasil dari analisis linier berganda dapat diketahui bahwa citra merek berpengaruh terhadap keputusan membeli.
\end{abstract}

Kata kunci: Citra Merek, Lifestyle, Keputusan Membeli.

\begin{abstract}
The study is to understand how brand image and lifestyle affects peter keiza decision to buy shoes at the Matahari Cito Surabaya Departement Store because a few years ago experienced a very drastic decline for that I took the initiative to look for one of the causes of decreased buyer interest in Matahari Cito Surabaya with brand image and lifestyle variables for the sample used as many 154 respondents. The variables used in this study are free variables (brand image and lifestyle)and associated variables (purchase decisions)for sampling samples using accidental sampling techniques and using linear regression analysis methods. The result of multiple linear analysis can be seen that brand image and lifestyle influence the buying decisions.
\end{abstract}

Keywords: Brand Image, Lifestyle, Purchase Decisions

PENDAHULUAN 
Di era milenial seperti sekarang ini, berbelanja merupakan hal yang sangat menyenangkan bagi beberapa masyarakat, untuk merefresh diri dari kegiatan yang dilakukan sehari-hari, dengan adanya social media, TV, internet yang sangat canggih dapat mempermudah masyarakat untuk mengetahui mode trend sekarang sehingga kita dapat menyesuaikan diri dan menghindarkan dari sebutan jadul (ketinggalan mode trend sekarang). Masyarakat dapat berpenampilan menarik untuk dapat meningkatkan kepercayaan diri seseorang. Oleh karena itu masyarakat dapat menemukan jati diri sendiri untuk berpenampilan menarik sesuai dengan hati nurani tanpa mencontoh penampilan setiap orang. Akses internet yang sangat mudah untuk sekarang masyarakat dapat dengan mudah mengetahui model penampilan yang lagi hits dari kalangan anak-anak sampai dengan kalangan dewasa. Dengan perkembangan yang saat ini sangat pesat dapat menguntungkan berbagai bisnis dari retail mulai dari bisnis baju, kosmetik, sepatu, accesories barang-barang tersebut didapatkan dengan cara yang mudah sehingga dapat meningkatkan omset penjualan dari bisnis retail tersebut melonjak tinggi.

Bisnis retail salah satunya yang ada di Indonesia untuk saat ini berkecenderungan mengalami penurunan yang lumayan signifikan dari setiap tahunnya, karena dengan adanya persaingan yang lumayan banyak dari bisnis online shop yang banyak diminati masyarakat. Bisnis online shop menurut masyarakat dapat dengan mudah membantu mendapatkan keinginan dari diri seseorang dan tanpa antri untuk melakukan pembelian produk tersebut. Apabila tidak cocok dengan barang tersebut atau adanya kerusakan dengan barang tersebut maka dapat dikembalikan kepada owner barang tersebut untuk mendapatkan barang yang baru lagi atau digantikan dengan barang lain.

Bisnis retail yang ada di Indonesia sampai dengan saat ini masih bisa berdiri kokoh dan nomor satu di Indonesia di bidang fashion milik Matahari department store. Meskipun dengan banyaknya persaingan-persaingan yang terjadi saat ini Matahari mampu berdiri dengan berbagai macam strateginya untuk mampu bersaing salah satunya dengan bisnis online shop yang lagi banyak diminati masyarakat. Matahari department store mampu membuka gerai-gerai baru yang banyak diminati karena matahari department store memberikan kepuasan dengan pelayanan yang sangat baik, memberikan produk-produk yang berkualitas tinggi, serta memberikan merek-merek yang ternama di Indonesia. Akan tetapi Matahari department store yang di wilayah Cito Surabaya akhir-akhir ini mengalami penurunan omset penjualan yang lumayan, adanya permasalahan tersebut pihak manajemen matahari department store wilayah cito surabaya memikirkan strategi yang menarik dengan salah satu cara visual merchandising yang tepat yang dapat dengan mudah mengkomunikasikan trend mode fashion yang ada sekarang dengan mengkombinasikan produkproduk yang ternama di Indonesia dengan berbagai tema yang terjadi saat ini dengan persetujuan dari perusahaan pusat. Tema yang ditentukan oleh manajemen pusat merupakan trend mode sekarang yang lagi ramai perbincangan di luar negeri maupun dalam negeri sendiri. Berbagai macam cara 
strategi dibuat oleh perusahaan agar dapat menarik minat konsumen lagi terhadap barang yang ada di toko matahari department store.

Dengan adanya merek-merek ternama yang dijual oleh pihak matahari department store sangat membantu pertahanan dan perkembangan bisnis retail untuk sekarang yang mempunyai persaingan yang sangat tinggi. Maka merek-merek ternama yang ada di Indonesia ini merupakan sangat penting, citra merek merupakan asosiasi yang muncul di benak konsumen ketika mengingat sebuah merek tertentu (Radji dan Lesmana, 2009). Dan dengan Gaya hidup (lifestyle) juga salah satu upaya untuk meningkatkan omset penjualan, untuk beberapa masyarakat yang menyukai berbelanja untuk mengikuti gaya hidup di masa sekarang mereka merelakan sesuatu yang dikeluarkan cukup tinggi untuk mendapatkan barang yang sangat diminati atau diinginkan untuk menunjang fashion mereka. Maka gaya hidup (lifestyle) dapat diartikan dengan perpaduan antara kebutuhan ekspresi diri dan harapan kelompok terhadap seseorang dalam bertindak berdasarkan pada norma yang berlaku (Nugrahani 2003). Menurunnya minat konsumen yang ada di matahari department store wilayah cito surabaya harus mengevaluasi strategi untuk meningkatkan omset penjualan yang diinginkan manajemen matahari dan penelitian ini untuk mengkaji faktor-faktor yang ada di diri konsumen untuk meningkatkan omset penjualan setiap harinya.

Dari beberapa penjelasan diatas maka didapat permasalahan yaitu citra merek berpengaruh terhadap keputusan membeli sepatu peter keiza, lifestyle berpengaruh terhadap keputusan membeli sepatu peter keiza, dan citra merek dan lifestyle berpengaruh terhadap keputusan membeli sepatu peter keiza di Matahari Department Store Cito Surabaya dengan bertujuan untuk mengetahui dan menganalisis citra merek berpengaruh terhadap keputusan membeli, untuk mengetahui dan menganalisis lifestyle berpengaruh terhadap keputusan membeli, dan untuk mengetahui dan menganalisis citra merek dan lifestyle berpengaruh terhadap keputusan membeli sepatu peter keiza di Matahari Department Store Cito Surabaya.

Berdasarkan uraian yang diatas, peneliti tertarik untuk melakukan penelitian dan mengambil judul "Pengaruh Citra Merek dan Lifestyle terhadap Keputusan Membeli sepatu peter keiza di Matahari Department Store Cito Surabaya".

\section{TINJAUAN PUSTAKA}

\section{Citra Merek}


Keller (2012) menjelaskan bahwa citra merek merupakan sebuah asset utama perusahaan yang di bentuk untuk menjaga kesinambungan antara perusahaan kepada pelanggan.

\section{Lifestyle}

Lifestyle, gaya hidup secara luas sebagai cara hidup yang diidentifikasikan oleh bagaimana orang menghabiskan waktu mereka apa yang mereka anggap penting dalam lingkungannya (berkaitan) dan apa yang mereka pikirkan tentang diri mereka sendiri dan sekitarnya (Nugroho 2003).

\section{Keputusan Membeli}

Kotler (2012) keputusan pembelian ialah suatu sikap seseorang dimana dia memilih salah satu dari beberapa opsi yang ada.

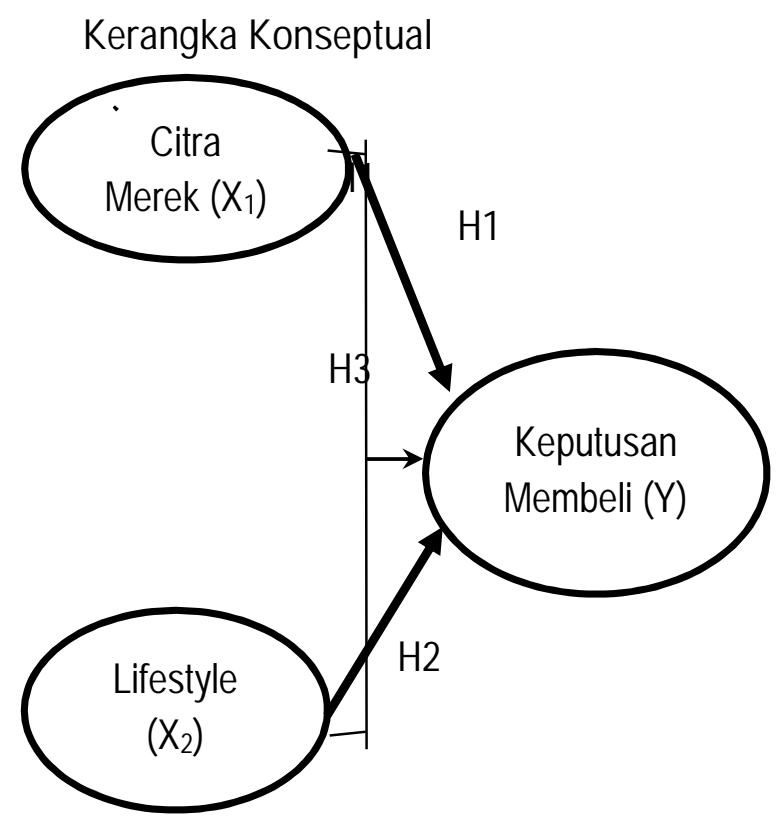

\section{Gambar 1 Kerangka konseptual}

Keterangan :

- $\quad$ : Pengaruh secara bersama-sama (simultan)

: Pengaruh secara parsial

Hipotesis 
Hipotesis yang akan di uji dalam penelitian ini adalah:

$\mathrm{H}_{1} \quad$ : Citra Merek $\left(\mathrm{X}_{1}\right)$ berpengaruh terhadap keputusan membeli $(\mathrm{Y})$ pada sepatu Peter Keiza

$\mathrm{H}_{2} \quad$ : Lifestyle $\left(\mathrm{X}_{2}\right)$ berpengaruh terhadap keputusan membeli $(\mathrm{Y})$ pada sepatu Peter Keiza

$\mathrm{H}_{3} \quad$ : Citra merek $\left(\mathrm{X}_{1}\right)$ dan lifestyle $\left(\mathrm{X}_{2}\right)$ berpengaruh terhadap keputusan membeli (Y) pada sepatu Peter keiza

\section{Metode Penelitian}

\section{Populasi dan Sampel}

Populasi di penelitian ini adalah konsumen yang membeli sepatu peter keiza di Matahari Department Store di bulan oktober sampai dengan november 2019 sebanyak 250 orang dengan sampel yang didapat 154 responden menggunakan rumus slovin dan teknik pengambilan sampel menggunakan accidental sampling.

\section{Teknik Pengumpulan Data}

Untuk teknik pengumpulan data yang digunakan dalam penelitian ini saya menggunakan kuesioner untuk mendapatkan data tersebut.

\section{Hasil dan Pembahasan}

Data deskriptif penelitian berjumlah 154 responden, data ini dapat menggambarkan keadaan atau kondisi responden untuk dapat mengetahui informasi tambahan memahami hasil dari penelitian, berikut diagram yang menunjukkan karakteristik dari responden: 


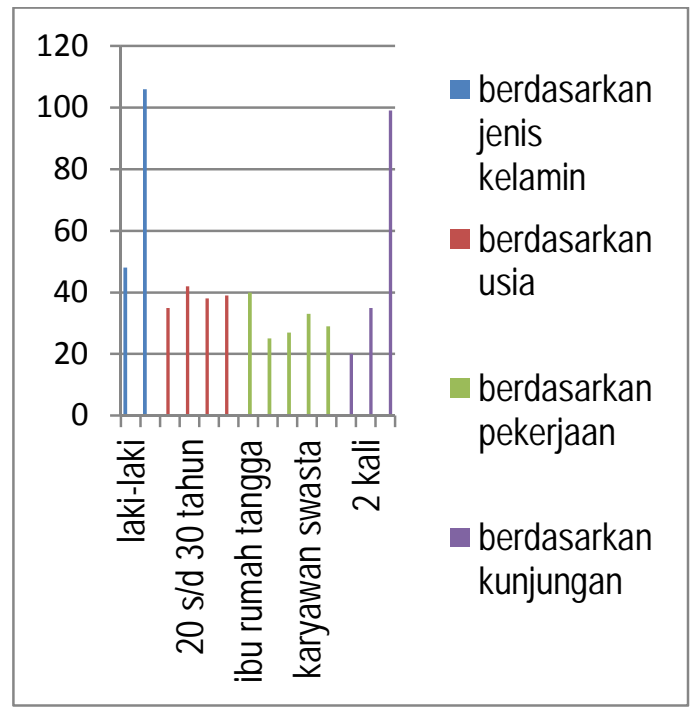

\section{Hasil Analisis Linier Berganda}

Hasil dari perhitungan tersebut menggunakan SPSS versi 23 dan didapatkan hasil seperti ini:

\section{Tabel 1}

Hasil Perhitungan Regresi Linier Berganda

Coefficients $^{\mathrm{a}}$

\begin{tabular}{lllll}
\hline \multirow{2}{*}{ Model } & $\begin{array}{l}\text { Unstand } \\
\text { ardized } \\
\text { Coefficie } \\
\text { nts }\end{array}$ & $\mathrm{t}$ & Sig. \\
\cline { 2 - 4 } & $\mathrm{B}$ & & \\
\hline & (Constant) & 3.092 & $\begin{array}{l}1.5 \\
09\end{array}$ & 0.133 \\
\hline $\begin{array}{l}\text { Citra } \\
1\end{array}$ & 0.751 & $\begin{array}{l}7.3 \\
\text { Merek } \\
\text { (X1) }\end{array}$ & 0.000 \\
\cline { 2 - 4 } $\begin{array}{l}\text { Lifestyle } \\
\text { (X2) }\end{array}$ & 0.396 & $\begin{array}{l}3.6 \\
81\end{array}$ & 0.000 \\
\hline
\end{tabular}

a. Dependent Variable: Keputusan Membeli (Y)

Sumber:Lampiran Output SPSS, Uji Regresi Linier Berganda

Dari tabel 1 maka diperoleh hasil persamaan regresi sebagai berikut:

$$
\mathrm{Y}=3,092+0,751+0,396+\mathrm{e}
$$

Keterangan: 
a. Nilai konstantanya sebesar 3,092

b. Nilai koefisien variabel citra merek X1 didapat sebesar 0,751

c. Nilai Koefisien variabel lifestyle X2 didapat sebesar 0,39

\section{Uji parsial}

Uji parsial ini untuk melihat apakah variabel bebas dari variabel citra merek (X1) dan variabel lifestyle (X2) berpengaruh secara parsial atau sendiri-sendiri terhadap keputusan membeli (Y) sepatu peter keiza. Berikut ini adalah hasilnya.

Tabel 2

Perhitungan Uji parsial

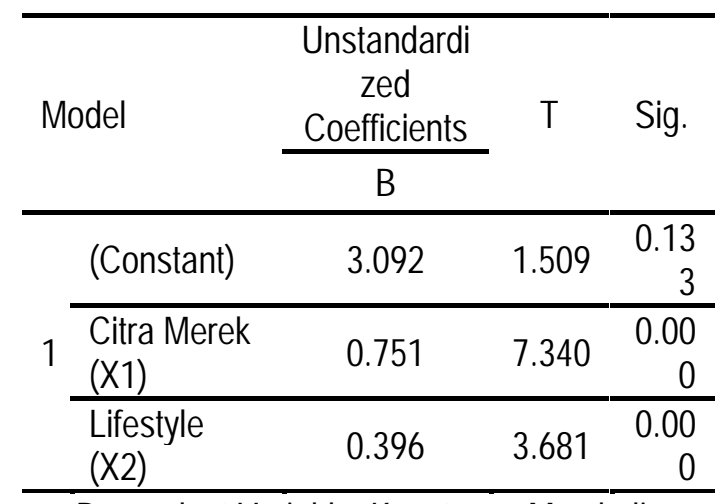

a. Dependent Variable: Keputusan Membeli

(Y)

Sumber:Lampiran Output SPSS, Uji -t

Hasil dari tabel 2 di peroleh:

1. Nilai t hitung diperoleh 7.340 dengan nilai signifikan sebesar $0.000<0,05$ yang dapat dinyatakan $\mathrm{HO}$ ditolak dan $\mathrm{H} 1$ diterima.

2. Nilai t hitung diperoleh 3.681 dengan nilai signifikan sebesar $0.000<0,05$ yang dapat juga dinyatakan $\mathrm{H} 0$ ditolak dan $\mathrm{H} 2$ diterima.

\section{Uji Simultan}


Uji simultan untuk dapat mengetahui apakah variabel citra merek (X1) dan lifestyle (X2) secara bersama-sama berpengaruh terhadap keputusan membeli $(Y)$ sepatu peter keiza. Adapun berikut ini adalah hasilnya:

Tabel 3

PERHITUNGAN UJI simultan

ANOVA

\begin{tabular}{|c|c|c|c|c|c|c|}
\hline \multicolumn{2}{|c|}{ Model } & \multirow{2}{*}{$\begin{array}{c}\text { Sum of } \\
\text { Square } \\
\text { S } \\
5608.7\end{array}$} & \multirow{3}{*}{$\begin{array}{r}\text { Df } \\
2\end{array}$} & \multirow{2}{*}{$\begin{array}{c}\text { Mean } \\
\text { Square }\end{array}$} & $\mathrm{F}$ & Sig. \\
\hline \multirow{4}{*}{1} & Regress & & & & 85.79 & .000 \\
\hline & ion & 41 & & 7 & 8 & b \\
\hline & Residual & $\begin{array}{r}4935.5 \\
25\end{array}$ & 151 & 32.686 & & \\
\hline & Total & $\begin{array}{r}10544 . \\
27\end{array}$ & 153 & & & \\
\hline
\end{tabular}

a. Dependent Variable: Keputusan Membeli (Y)

b. Predictors: (Constant), Lifestyle (X2), Citra Merek (X1)

Sumber:Lampiran Output SPSS, Uji-F

Hasil dari tabel 3 diperoleh $\mathrm{F}$ hitung 85.798 dengan nilai signifikan sebesar $0.000<0,05$ maka dari pengujian hipotesis tersebut dinyatakan diterima.

\section{PEMBAHASAN}

H1 : hasil dari hipotesis 1 menggunakan Uji-t didapat nilai 7,340 nilai signifikasi $.000<0,05$ dinyatakan dapat diterima untuk $\mathrm{HO}$ ditolak jadi dapat dikatakan bahwa secara parsial variabel citra merek berpengauh positif terhadap keputusan membeli maka nilai dari citra merek dapat menaikkan keputusan pembelian sepatu peter keiza.

H2 : hipotesis 2 menggunakan Uji-t dengan nilai didapat 3,681 nilai signifikasi $0.000<0,05$ dinyatakan $\mathrm{H} 2$ nya di terima untuk $\mathrm{HO}$ ditolak jadi untuk $\mathrm{H} 2$ secara parsial variabel lifestyle dapat berpengaruh positif dan nilai dari lifestyle dapat meningkatkan keputusan membeli sepatu peter keiza.

H3 : hipotesis 3 ini menggunakan Uji F dengan hasil 85,798 nilai signifikasi $0.000<0,05$ hasil yang diajukan diterima, untuk variabel citra merek (X1) dan lifestyle (X2) secara serentak dapat berpengaruh kepada keputusan membeli, jadi setiap peningkatan nilai dari kedua variabel yaitu citra merek (X1) dan lifestyle (X2) dapat meningkatkan keputusan membeli sepatu peter keiza di Matahari Department Store Cito Surabaya.

\section{SIMPULAN}


Penelitian ini menunjukkan bahwa setiap variabel secara parsial dari variabel citra merek berpengaruh signifikan dan positif terhadap keputusan membeli sepatu peter keiza, variabel lifestyle juga secara parsial berpengaruh signifikan dan positif terhadap keputusan membeli sepatu peter keiza, begitu juga dengan variabel citra merek dan lifestyle yang secara serentak juga berpengaruh signifikan dan positif terhadap keputusan membeli sepatu peter keiza di Matahari Department Store CITO Surabaya.

\section{IMPLIKASI}

Hal ini harus dapat perhatian yang lebih extra karena untuk meningkatkan penjualan sepatu peter keiza, perusahaan dapat memberikan kepuasan terhadap konsumen untuk membeli produk ini dengan meningkatkan citra merek dan selalu mengevaluasi lifestyle yang terbaru dari tahun ke tahun untuk mempertahankan produk yang selama ini dicapai, selain itu juga dapat meningkatkan konsumen dalam keputusan membeli secara terus menerus dari produk sepatu peter keiza yang ada di Matahari Department Store.

\section{Keterbatasan Penelitian}

keterbatasan penelitian ini adalah responden yang ditentukan karena untuk dapat mengetahui hasil dari responden peneliti membagikan kuesioner dari setiap responden yang membeli sepatu peter keiza di Matahari Department Store Cito Surabaya.

\section{DAFTAR PUSTAKA}

Kotler, P. \& Amstrong, G. (2012), Prinsip-Prinsip Pemasaran Edisi 12 penerbit Erlangga.

Kurniawan, R., \& Susanti, F. . "Pengaruh lifestyle terhadap keputusan pembelian pada sepatu merek fladeo di basko grand mall padang," 2018.

Nugroho, Perilaku Konsumen (Konsep dan Implikasi Untuk Strategi dan PenelitianPemasaran). Yogyakarta: Andi, 2003.

Rizky, F., \& Utomo, A. (2017). Pengaruh Brand Image, Brand trust, dan Perceived Quality terhadap Brand Loyalty ADIDAS pada Chelsea Indonesia Supporter Club (CISC) di Depok. Jurnal IImu Manajemen, 13(2). 